\title{
HUBUNGAN ANTARA JUMLAH ROKOK YANG DI KONSUMSI DENGAN INSOMNIA PADA ORANG DEWASA
}

\author{
I Gede Purnawinadi ${ }^{1}$, Maisyeliani Angelia Baureh ${ }^{2}$ \\ ${ }^{1,2}$ Fakultas Keperawatan, Universitas Klabat, Airmadidi, Minahasa Utara, 95371, Indonesia \\ E-mail:purnawinadi87@unklab.ac.id
}

\begin{abstract}
Insomnia is a symptom that a person experiences when experiencing chronic sleep difficulties, often awakens from sleep, short sleep or non-resortative sleep. A smoker needs more sleep time to fall asleep compared to non-smokers. The more often someone or the more cigarettes consumed or smoked in a day, the higher the insomnia will be experienced. This study aims to determine the relationship of the number of cigarettes with the incidence of insomnia in Kaima Village, Kauditan District. The research design used was descriptive correlation with cross-sectional approach, using purposive sampling technique with a sampling of 80 respondents. The results found were 34 respondents $(42.5 \%)$ with moderate smoker consumption (11-20 stems), and the picture of the most respondent insomnia was 37 respondents (46.3\%) with mild insomnia. The results of the Spearman Correlation statistical test showed a significant value of $p=0.030<0.05$ with weak correlation coefficients where $r=0.243$ in a positive direction. There is a relationship between the number of cigarettes and the incidence of insomnia in Kaima Village, Kauditan Subdistrict. It is recommended for future researchers to add variables to the duration of smoking, gender, and age of the respondent. It is hoped that the people of the village of Kaima Kecacmatan Kauditan can change their smoking behavior, namely reducing the number of cigarettes consumed or can even stop smoking.
\end{abstract}

Keywords: Insomnia, Amount of Cigarette Consumption

\begin{abstract}
Abstrak
Insomnia merupakan gejala yang dialami seseorang ketika mengalami kesulitan tidur kronis, sering terbangun dari tidur, tidur pendek atau tidur non-resoratif. Seorang perokok membutuhkan waktu tidur lebih lama untuk dapat tertidur dibandingkan dengan yang tidak merokok. Semakin sering seseorang atau semakin banyak jumlah rokok yang dikonsumsi atau yang dihisap dalam sehari maka semakin tinggi insomnia yang akan dialami. Penelitian ini bertujuan untuk mengetahui hubungan jumlah rokok dengan kejadian insomnia di Desa Kaima Kecamatan Kauditan. Desain penelitian yang digunakan yaitu deskriptif korelasi dengan pendekatan cross-sectional, menggunakan teknik pengambilan sampel purposive sampling dengan jumlah sampling 80 responden. Hasil yang didapati secara deskriptif 34 responden $(42,5 \%)$ dominan sebagai konsumsi perokok sedang (11-20 batang), dan 37 responden (46,3\%) dominan sebagai insomnia ringan. Hasil uji statistik Spearman Correlation menunjukkan nilai signifikan $\mathrm{p}=0,030<0,05$ dengan koefisiensi korelasi lemah dimana $\mathrm{r}=0,243$ dengan arah yang positif. Ada hubungan jumlah rokok dengan kejadian insomnia di Desa Kaima Kecamatan Kauditan. Direkomendasikan bagi peneliti selanjutnya untuk menambahkan variabel durasi merokok, jenis kelamin, dan umur responden. Bagi masyarakat Desa Kaima Kecamatan Kauditan diharapkan dapat mengubah perilaku merokok yaitu mengurangi jumlah rokok yang dikonsumsi atau bahkan bisa berhenti merokok.
\end{abstract}

Kata Kunci: Insomnia, Jumlah Konsumsi Rokok 


\section{Pendahuluan}

Tidur merupakan kebutuhan dasar yang diperlukan oleh manusia, untuk dapat berfungsi secara optimal maka setiap orang memerlukan tidur yang cukup. Tidur merupakan keadaan bawah sadar yang dialami oleh seseorang yang dapat dibangunkan dengan indera atau rangsangan yang cukup. Manfaat dari tidur adalah untuk menjaga keseimbangan mental, emosional, dan kesehatan (Guyton \& Hall, 2014). Kozier, Erb, Berman dan Snyder (2010) menjelaskan bahwa tidur sebagai kebutuhan dasar manusia sering kali tidak terpenuhi dengan benar karena adanya berbagai macam gangguan tidur seperti banyaknya aktivitas sehingga menyita waktu tidur seseorang, tidur yang terlalu larut dan gangguan yang juga sering terjadi seperti insomnia. Kebutuhan tidur yang tidak terpenuhi akan mengganggu kualitas tidur dan kesehatan seseorang.

Merokok merusak kesehatan seseorang. Jika seseorang merokok, ia harus berhenti. Kandungan dalam rokok yaitu nikotin merupakan stimulan dan dapat menyebabkan insomnia, bahkan jika mengkonsumsi produk tembakau yaitu rokok menjelang tidur dapat menyulitkan seseorang untuk tertidur (National Sleep Foundation, 2018).

Data WHO menunjukkan bahwa prevalensi merokok pada tahun 2015, lebih dari 1,1 miliar orang merokok. Jauh lebih banyak laki-laki daripada perempuan. Pada tahun 2016 untuk prevalensi laki-laki yang merokok sebesar $33,7 \%$ dan untuk perempuan sebesar 6,2\% (World Health Organization, 2018). Riset Kesehatan Dasar (2013), menyebutkan Indonesia dari tahun 2007 ke tahun 2013 dimana penduduk usia 15 tahun ke atas masih belum terjadi penurunan. Pada tahun
2007 prevelensi sebesar 34,2\% dan pada tahun 2010 prevelensi sebesar 36,3\%. Adapun data yang diambil dari Riset Kesehatan Dasar (2013) menunjukkan prevalensi perokok 16 kali lebih tinggi pada laki-laki $(65,8 \%)$ dibandingkan perempuan $(4,2 \%)$. Sementara itu menurut data dari riset kesehatan dasar (RIKESDAS) dalam Angka tahun 2013, Sulawesi Utara mendapatkan 24,6\% (perokok setiap hari), 5,9\% (perokok kadang-kadang), 6,2\% (mantan perokok), dan $63,3 \%$ (bukan perokok).

Menurut Sanchi dalam Kairupan, Rottie dan Malara (2016) seorang perokok ternyata membutuhkan waktu lebih lama untuk dapat tertidur dibandingkan dengan orang yang tidak merokok. Nikotin akan hilang dari otak dalam waktu 30 menit. Tetapi reseptor di otak seorang pecandu seolah menagih nikotin lagi, sehingga mengganggu proses tidur. Semakin banyak jumlah batang rokok yang dihisap dalam sehari maka akan semakin tinggi tingkat insomnia yang akan dideritanya, hal ini karena salah satu zat yang ada di dalam rokok yaitu nikotin. Nikotin digolongkan dalam kelompok zat stimulan. Efek stimulan dari nikotin yang kuat akan menyebabkan gangguan tidur.

Ketika seseorang menghisap rokok, maka nikotin yang terkandung dalam rokok akan meresap, kemudian nikotin akan diterima oleh reseptor indera perasa di dalam lidah dan akan diteruskan ke otak. Dalam perjalan menuju otak, nikotin akan melewati batang otak yang disebut hypotalamus. Hypotalamus ini berfungsi untuk mengeluarkan hormon dopamine dan serotonin, sesuai dengan stimulus yang sesuai bagi masing-masing hormon. Nikotin akan memicu pengeluaran hormon dopamin yang akan merangsang otak, bersama dengan nikotin yang akan diteruskan ke otak, yaitu memberikan 
rasa tenang, meningkatkan konsentrasi, memacu otak untuk lebih keras dalam bekerja, memberi rasa segar dan menghilangkan rasa kantuk, dan memacu aktivitas kognitif lainnya. Secara psikologis seseorang akan merasakan kenyamanan dan bebas dari rasa tertekan atau depresi. Saat seseorang merasakan kenyamanan, yaitu saat nikotin ini sudah merangsang hormon dopamin keluar menuju ke otak, mengakibatkan aktifitas kognitif dalam otak meningkat, maka saraf-saraf pun akan ikut bekerja dan berkontraksi. Dalam tahapam ini terjadilah kontradiksi, dimana seseorang yang sebenarnya ingin tidur atau masuk dalam kondisi bawah sadar, malahan mengalami susah tidur karena proses mental atau aktifitas kognitifnya tidak bisa dihentikan, dikarenakan tetap bekerja atau pikirannya terjebak dalam kondisi sadar (Putra dalam Kairupan, Rottie dan Malara, 2016).

Penelitian yang dilakukan oleh Kairupan, Rottie dan Malara (2016) didapati seorang yang merokok mengalami insomnia jangka pendek yang berlangsung selama 1-4 minggu yang disebabkan karena rokok yang dikonsumsinya dalam sehari dapat mencapai 5-14 batang rokok, dimana seseroang yang merokok mengkonsumsi rokok bersama teman-teman dimalam hari. Hal ini menyebabkan orang tersebut mengalami gejala insomnia dimana sulit untuk tidur, sulit untuk mempertahankan tidur dengan jam tidur maksimal dan sering terbangun pada malam hari. Pada dasarnya nikotin pada otak akan hilang dalam waktu 30 menit tetapi reseptor otak seorang perokok yang dapat menghabiskan 5-14 batang rokok dalam sehari seolah akan menagih nikotin lagi dan lagi sehingga mampu mengganggu proses tidur itu sendiri.
Studi pendahuluan yang telah dilakukan oleh peneliti di Desa Kaima Kecamatan Kauditan, Kabupaten Minahasa Utara menemukan 5 dari 10 perokok yang diketahui menghabiskan 10-12 batang per hari. Para perokok juga mengeluhkan sulit untuk tidur pada malam hari, terbangun pada tengah malam, merasa tidak puas tidur pada saat bangun pagi hari, dan merasa kantuk disiang hari. Sehubungan dengan latar belakang tersebut peneliti tertarik untuk melakukan penelitian mengenai hubungan antara jumlah rokok yang dikonsumsi dengan kejadian Insomnia ada orang dewasa.

\section{Metode}

Penelitian ini merupakan analisis deskriptif menggunakan metode kuantitatif dengan pendekatan crosssectional. Sampel diambil menggunakan purposive sampling, berdasarkan studi pendahuluan yang telah dilakukan pada bulan Oktober 2018 di Desa Kaima Kecamatan Kauditan, Kabupaten Minahasa Utara. Berdasarkan rumus slovin yaitu 80 sampel dari 100 populasi yang memenuhi kriteria inklusi dan eksklusi dengan waktu pengambilan data pada bulan Januari 2018 .

Responden dalam penelitian ini adalah masyarakat orang dewasa yang bersedia memberikan jawaban dengan jujur, dan menandatangani informed consent. Subyek yang tidak termasuk dalam penelitian ini merupakan orang dewasa yang perokok pasif, yang tidak berdomisili di Desa Kaima Kec. Kauditan.

Instrumen yang digunakan pada penelitian ini berupa kuesioner. Kuesioner yang digunakan dalam penelitian ini terbagi menjadi dua yaitu: yang pertama adalah kuesioner jumlah rokok yang terdiri dari 3 pernyataan 
yaitu: merokok kurang lebih 1-10 batang/hari (perokok ringan), merokok 11-20 batang/hari (perokok sedang), dan merokok > 20 batang/hari (perokok berat), kuesioner yang kedua untuk insomnia adalah diadopsi dari kuesioner KSPBJ-IRS (Kelompok Studi Psikiatri Biologi Jakarta-Insomnia Rating Scale), kuesioner ini memiliki hasil uji validitas dan reliabillitas dengan nilai Alpha Cronbach's 0,916 (Perwiraningtyas, 2016). Kuesioner ini terdiri dari 11 pertanyaan. Alat ukur ini menggunakan skala ordinal yaitu jawaban diberi nilai $0,1,2$, dan 3. Jumlah total skor dapat dikategorikan sebagai berikut:

Tabel 1. Interpretasi Skor Insomnia

\begin{tabular}{ccc}
\hline Kategori & Skor & Interpretasi \\
\hline 0 & $<11$ & Tidak Insomnia \\
1 & $11-17$ & Insomnia Ringan \\
2 & $18-24$ & Insomnia Sedang \\
3 & $25-33$ & Insomnia Berat \\
\hline
\end{tabular}

Data olah secara deskriptif melalui analisis univariat menggunakan persentase dan bivariat menggunakan rumus statistik Spearman Correlation pada komputer yang terinstall software Statistical Product and Service Solution (SPSS).

\section{Hasil}

Gambaran jumlah rokok yang dikonsumsi dan kejadian insomnia pada orang dewasa di Desa Kaima Kecamatan Kauditan dapat dilihat pada tabel-tabel berikut:

\section{Tabel 2. Distribusi Frekuensi}

\section{Konsumsi Jumlah Rokok}

\begin{tabular}{lcc}
\hline Jumlah Rokok & Frekuensi & $\%$ \\
\hline 1-10 batang/hari & 25 & 31,3 \\
11-20 batang/hari & 34 & 42,5 \\
> 20 batang/hari & 21 & 26,2 \\
Total & 80 & 100 \\
\hline
\end{tabular}

Gambaran jumlah rokok yang dikonsumsi pada orang dewasa di Desa Kiama Kecamatan Kauditan dari 80 responden terdapat 25 responden $(31,3 \%)$ dengan jumlah rokok 1-10 batang/hari, 34 responden $(42,5 \%)$ 1120 batang/hari, dan 21 responden $(26,3 \%)$ dengan $>20$ batang/hari. Sesuai dengan hasil uji statistik didapati kategori perokok pada orang dewasa di Desa Kaima Kecamatan Kauditan yang paling banyak adalah perokok sedang.

Tabel 3. Distribusi Frekuensi Insomnia

\begin{tabular}{lcc}
\hline Kategori & Frekuensi & $\%$ \\
\hline Tidak Insomnia & 30 & 37,5 \\
Insomnia Ringan & 37 & 46,3 \\
Insomnia Sedang & 13 & 16,2 \\
Total & 80 & 100 \\
\hline
\end{tabular}

Gambaran insomnia di Desa Kaima Kecamatan Kauditan dari 80 responden yang paling dominan yaitu 37 responden (46,3\%) dengan insomnia ringan, disusul dengan 30 responden $(37,5 \%)$ dengan tidak insomnia, dan hanya 13 responden $(16,3 \%)$ dengan insomnnia sedang.

Tabel 4. Hubungan Jumlah Rokok yang dikonsumsi dengan Insomnia

\begin{tabular}{lc}
\hline Spearman's rho & $\begin{array}{c}\text { Jumlah Rokok } \\
\text { dan Insomnia }\end{array}$ \\
\hline Correlation Coefficient & $0,243^{*}$ \\
Sig. (2-tailed) & 0,030 \\
$\mathrm{~N}$ & 80 \\
\hline *. Correlation is significant at the 0.05 level (2-tailed).
\end{tabular}

Hasil yang diperoleh pada tabel 4 yaitu $p$ value $=0,030<0,05$, dengan demikian bahwa pada alpha 5\% ada hubungan yang signifikan antara jumlah rokok yang dikonsumsi dengan kejadian insomnia di Desa Kaima Kecamatan Kauditan. Tingkat hubungan kedua variabel rendah dimana $r=0,243$ dan memiliki arah yang positif, yang artinya semakin banyak jumlah rokok yang 
dikonsumsi per hari maka semakin berat kondisi insomnia begitu juga sebaliknya.

\section{Pembahasan}

Menurut Sitepoe dalam Putra (2013) perokok sedang adalah yang merokok 11-20 batang/hari dan sesuai dengan hasil penelitian yang didapat oleh peneliti dimana di Desa Kaima Kecamatan Kauditan didapati responden adalah perokok sedang. Menurut Sarafino \& Smith (2011) faktor- faktor yang menyebabkan perilaku merokok yaitu, faktor biologis, psikologis, lingkungan sosial, demografis. Penelitian ini sama dengan hasil penelitian yang dilakukan oleh Firdaus (2018) yang dilakukan pada 106 responden dan didapati 51 responden (48\%) dengan jumlah rokok 5-14 batang/hari (perokok sedang).

Banyaknya jumlah rokok sedang dikarenakan dari jawaban kuesioner, sebanyak 34 responden menjawab merokok 11-20 batang/hari. Ketika peneliti bertanya, responden menjawab hanya merokok ketika bersama teman, pada saat ada waktu senggang ketika bekerja atau ketika waktu istirahat, sehingga jumlah rokok yang mereka konsumsi termasuk dalam kategori perokok sedang.

Menurut Rahmadhani (2014) insomnia ringan memiliki tanda dan gejala sebagai berikut yaitu, tidur selama 5,5-6,5 jam, terkadang mimpi menyenangkan atau mimpi biasa saja, tidur nyenyak dan sulit terbangun, 30 menit-1 jam untuk dapat tertidur, 1-2 kali terbangun pada malam hari, 30 menit - 1 jam untuk dapat tertidur kembali setelah terbangun, lamanya tidur setelah bangun 1-3 jam, lamanya gangguan tidur 2-7 hari, bangun 30 menit lebih cepat dari biasanya, lamanya perasaan tidak segar setiap bangun pagi yaitu 2-7 hari.
Insomnia adalah kesukaran dalam memulai dan mempertahankan tidur sehingga tidak dapat memenuhi kebutuhan tidur yang adekuat, baik kuantitas maupun kualitas (Saputra, 2013). Faktor-faktor penyebab insomnia adalah stres, jadwal perjalanan atau kerja, kebiasaan tidur yang buruk, makan terlalu larut malam, gangguan kesehatan mental, obat-obatan, kondisi medis, gangguan terkait tidur, kafein, nikotin, dan alkohol (Mayo Clinic, 2016). Hasil penelitian ini sejalan dengan penelitian yang dilakukan oleh Puspitasari, Santoso, \& Permatasari (2014) di mana didapati pada 193 responden menunjukan 70 responden $(36,27 \%)$ dengan kategori insomnia ringan.

Insomnia adalah gejala yang dialami seseorang ketika mereka mengalami kesulitan tidur kronis, sering terbangun dari tidur, dan/atau tidur pendek atau tidur non-resoratif. Ini adalah keluhan tidur yang paling umum. Para penderita insomnia mengeluh kantuk yang berlebihan di siang hari, serta kuantitas dan kualitas tidur yang tidak memadai. Namun sering kali seseorang yang menderita insomnia tidur lebih lama dari yang disadari (Potter \& Perry, 2010).

Insomnia pada penelitian ini paling dominan adalah insomnia ringan. Jika ditinjau dari kuesioner, sebanyak 37 responden menjawab mengalami insomnia ringan dikarenakan lamanya tidur atau kebutuhan jam tidur tidak tercukupi, mendapatkan mimpi, kualitas tidur tidak normal atau tidur tidak nyenyak, sulit utuk masuk tidur atau memulai untuk tidur, terbangun pada malam hari dan sulit untuk tertidur kembali, lamanya gangguan tidur 2-7 hari, terbangun dini hari (bangun lebih cepat dari jam biasanya), dan mengalami perasaan yang tidak segar ketika bangun 
di pagi hari, dan ada faktor-faktor yang lain sehingga menyebabkan insmonia ringan.

Hasil penelitian ini sejalan dengan hasil penelitian yang dilakukan oleh Putra (2013) yaitu terdapat hubungan yang signifikan antara Intensitas Perilaku Merokok dengan Tingkat Insomnia adalah sebesar 0,386 dengan taraf signifikan $\mathrm{p}=0,002$ dimana $\mathrm{p}<0,05$. Begitu juga dengan hasil penelitian yang dilakukan oleh Firdaus (2018) didapati ada hubungan antra perilaku merokok dengan kecenderungan nsomnnia pada pekerja dengan nilai signifikan 0,004 < 0,05 dengan nilai korelasi positif 0,280. Juga dalam penelitian yang dilakukan oleh Diani, Hariyanto, Ardiyani (2016) yang meneliti tentang hubungan antara perokok aktif dengan gangguan kualitas tidur (Insomnia) di RW 04 Desa Kalisongo Kecamatan Dau Kabupaten Malang didapati ada hubungan yang singnifikan yaitu $0,004<0,05$ dimana didapati $50 \%$ orang dewasa dinyatakan perokok berat, sedangkan sebagian besar $52,5 \%$ responden dinyatakan mengalami insomnia.

\section{Kesimpulan}

Secara deskriptif perokok di Desa Kaima dominan sebagai perokok sedang dengan konsumsi 11-20 batang per hari, dan dominan dalam kategori insomnia ringan. Ada hubungan yang signifikan ddengan arah posistif antara jumlah rokok dengan kejadian insomnia di Desa Kaima Kecamatan Kauditan.

Hasil penelitian ini diharapkan agar masyarakat Desa Kaima Kecamatan Kauditan dapat memotivasi diri sendiri untuk menurunkan jumlah rokok yang dikonsumsi atau bahkan bisa berhenti merokok, bermanfaat sebagai referensi bahan pembelajaran, dan institusi pendidikan dihimbau untuk membuat penyuluhan kesehatan tentang bahaya merokok dan hubungannya dengan insomnia di daerah terkait.

Peneliti selanjutnya yang akan melakukan penelitian dengan judul yang sama dapat menambahkan variabel lain durasi merokok, jenis kelamin, dan umur responden agar dapat menjadi tambahan referensi dan dikarenakan durasi merokok setiap orang berbeda-beda dan bahkan ada yang sudah berhenti dan merokok kembali, untuk jenis kelamin yang merokok bukan hanya pria melaikan wanita juga ada dan untuk umur seponden berbeda-beda dan semakin tua umur seseorang maka waktu tidur lebih berkurang.

\section{Referensi}

Diani., Hariyanto, T., \& Ardiyani, V, M. (2016). Hubungan antara perokok aktif dengan gangguan kualitas tidur (insomnisa) pada dewasa (umur 25-45 tahun) di RW 04 Desa Kalisongo Kecamatan Dau Kabupaten Malang. Nursing News, 2, 152.

Firdaus, H. (2018). Hubungan antara perilaku merokok dengan kecenderungan insomnia pada Pekerja. Skripsi. Universitas Islam Negeri Sunan Ampel Surabaya.

Guyton, A. C., \& Hall, J. E. (2014). Buku ajar fisiologis kedokteran. Singapore: Elsevier.

Kairupan, J. M. A., Rottie, J. V., Malara, R. T. (2016). Hubungan merokok dengan kejadianinsomnia pada remaja di SMA Negeri 1 Romboken Kabupaten Minahasa. E-jurnal Keperawatan, 4, 6. 
Kozier, B., Erb, G., Berman, A., \& Snyder, S. (2010). Buku ajar fundamental: konsep, proses, dan praktik (7 ed., Vol. 2). Jakarta: EGC.

Mayo Clinic. (2016). Insomnia. Diakses dari Mayo Clinic: https://www.mayoclinic.org/diseas es-conditions/insomnia/symptomscauses/syc-20355167

National Sleep Foundation. (2018). What cause insomnia. Diakses dari National Sleep Foundation: https://www.sleepfoundation.org/in somnia/content/what-insomnia

Potter, P., \& Perry, A. (2010). Fundamental of nursing. Singapore: Elsevier.

Puspitasari, M. D., Santoso, T. H., \& Permatasari, E. (2014). Hubungan perilaku merokok dan kejadian insomnia pada mahasiswa lakilaki Universitas Muhammadiyah Jember. Skripsi. Universitas Muhammadiyah Jamber.

Putra, Bima A. (2013). Hubungan antara intensitas perilaku merokok dengan tingkat insomnia. Semarang. Skripsi. Universitas Negeri Semarang.

Rahmadhani, V. S. (2014). Hubungan sters dengan kejadian insomnia pada lansia di Panti Sosial Tresna Werdha Kasi Sayang Ibu Batusangkar. Skripsi. Universitas Muhammadiah Sumatera Barat Bukit Tinggi.

Saputra, L. (2013). Catatan ringkasan kebutuhan dasar manusia. Tanggerang Selatan: Binarupa Aksara.
Sarafino, E. P., \& Smith, T. W. (2011). Health pshychology biopsychosocial interactions. United State of America: John Wiley \& Sons, INC.

Riset Kesehatan Dasar. (2013). Diakses dari Departemen Kesehatan: http://www.depkes.go.id/resources/ download/general/Hasil\%20Riskes das\%202013.pdf?opwvc $=1$

World Health Organization. (2018). Prevalance of Tabacco Smoking. Diakses dari World Health Organization:

https://www.who.int/gho/tobacco/u selen 